\title{
Estimating Risk Using Bounding Calculations and Limited Data
}

William L. Cowley

Joseph E. Meacham

Duke Engineering \& Services, Inc.

Date Published

March 1999

To Be Presented at American Institute of Chemical Engineers 1999 Spring Meeting Houston, Texas

March 14-18, 1999

Prepared for the U.S. Department of Energy

FLUOR DANHEL MANFORD, INC.

P.O. Box 1000

Richland, Washington

Hanford Management and Integration Contractor for the

U.S. Department of Energy under Contract DE-AC06-96RL13200

Copyright License By acceptance of this article. the publisher and/or recipient acknowledges the U.S. Government's right to retain a nonexclusive, royalty-free license in and to any copyright covering this paper.

Approved for Public Release; Further Dissemination Unlimited 
HNF-4107-FP

\title{
Estimating Risk Using Bounding Calculations and Limited Data
}

\author{
By: William L. Cowley \\ Joseph E. Meacham \\ Duke Engineering \& Services, Hanford \\ Richland, WA.
}

\begin{abstract}
This paper describes a methodology for estimating the potential risk to workers and the public from igniting organic solvents in any of the 177 underground waste storage tanks at the Hanford Site in southeastern Washington state. The Hanford Site is one of the U.S. Department of Energy's former production facilities for nuclear materials. The tanks contain mixed radioactive wastes. Risk is measured by calculating toxicological and radiological accident consequences and frequencies and comparing the results to established regulatory guidelines. Available sample data is insufficient to adequately characterize the waste and solvent, so a model that maximizes releases from the tanks (bounding case) is used. Maximizing releases (and thus consequences) is a standard technique used in safety analysis to compensate for lack of information. The model predicts bounding values of fire duration, the time at which the fire extinguishes because of lack of oxygen, and a pressure history of a fire in a tank. The model output is used to calculate mass and volume release rates of material from the tanks. The mass and volume release rates permit calculation of radiological and toxicological consequences. The resulting consequence calculations demonstrate that risk from an organic solvent fire in the tanks is within regulatory guidelines.
\end{abstract}

\subsection{Introduction}

There are 177 large, underground storage tanks at the Hanford Site that contain mixed radioactive wastes. The volumes of the tanks range from 55,000 gal. (208 kL) to 1,000,000 gal. $(3,785 \mathrm{~kL})$. The wastes were generated over approximately 40 years by chemical separation plants that recovered plutonium from irradiated reactor fuel. Several separation processes were used. The most recent was a solvent extraction process that used a mixture of $70 \mathrm{vol} \%$ normal paraffin hydrocarbons (NPH) and 30 vol\% tributyl phosphate (TBP). An estimated 657,000 gal. $(2,487 \mathrm{~kL})$ of this mixture was sent to the underground storage tanks.

It was assumed for many years that all the TBP-NPH mixture had evaporated and degraded, and was not present in any significant quantities in the tanks. However, a floating layer of TBP-NPH was discovered in underground storage tank 241-C-103 in 1992. The discovery of the floating solvent layer resulted in an intensive safety analysis program to quantify the potential risks of a fire in the underground storage tank. Examination of photographs of the interior as well as a 
sampling program of the headspaces of other tanks, lead to the conclusion that additional tanks could contain this solvent mixture as a separable phase.

This paper outlines the methodology that was used to estimate the risk that a solvent fire would pose to a Hanford Site worker located 100 meters from a tank containing a solvent fire and to a member of the public located at the boundary of the Hanford Site. Risk is measured by comparison to risk evaluation guidelines published by the U.S. Department of Energy (DOE). Because of the time, difficulty, and cost required to sample the underground tanks, it was desirable to make a determination about risk with as little additional sampling as possible.

\subsection{Description of Tanks}

The Hanford Site has 177 underground waste storage tanks that have capacities ranging from 55,000 gal. $(208 \mathrm{~kL})$ to $1,000,000 \mathrm{gal} .(3,785 \mathrm{~kL})$. The tanks are grouped into farms ranging from 2 to 18 tanks per farm. All of the tanks are based on concrete cylinders that are either $25 \mathrm{ft}$. (7.6 $\mathrm{m})$ or $75 \mathrm{ft} .(23 \mathrm{~m})$ in diameter with dished bottoms and convex tops or domes. Some tanks (single-shell tanks or SSTs) have a steel liner that forms a cup inside the cylinder. Other tanks have two steel liners (double-shell tanks or DSTs). One liner covers the entire inside of the concrete cylinder, including the dome, and the second is a cup inside the first liner. The DSTs and SSTs have different structural failure pressures. The DSTs begin to crack (but not collapse) at an approximate internal pressure of 45 pounds per square inch gauge $\left(\mathrm{lb} / \mathrm{in}^{2}\right.$ [gauge] $)(310.2$ $\mathrm{kPa}$ [gage]). The SSTs begin to crack (but not collapse) at an approximate internal pressure of 11 to $14 \mathrm{lb} / \mathrm{in}^{2}$ (gauge) (75.8 to $96.5 \mathrm{kPa}$ [gage]).

The DSTs are equipped with ventilation systems that consist of a fan drawing air out of the tanks through banks of high efficiency particulate air (HEPA) filters. Inlet air is provided through an open riser equipped with a HEPA filter. The SSTs have passive ventilation. One riser on each tank is open and has a HEPA filter mounted onto it. The atmosphere in the SSTs changes slowly because of changes in atmospheric pressure and temperature differentials between the waste and ambient air.

The actual inventories of waste in individual tanks ranges from approximately 9,000 gal. (34 kL) to $1,000,000$ gal. $(3,785 \mathrm{~kL})$.

\subsection{Constraints on Sampling Waste Tanks}

The wastes in the underground storage tanks were generated in separations plants using significantly different processes, then sent to tanks where wastes were precipitated and evaporated, also by different processes. Wastes were pumped from tank-to-tank. As a result, while the same radionuclides and chemicals may be in all the tanks, the concentrations vary from tank-to-tank. Wastes are similar in that they are moderately to highly basic and have high concentrations of hydroxides, nitrate salts, and water. The wastes have generated elevated temperatures and high radiation fields during their storage. 
Waste samples are obtained through risers, vertical pipes that penetrate the tank domes and range in diameter from $2 \mathrm{in.}(5.1 \mathrm{~cm})$ to $42 \mathrm{in.}(106.7 \mathrm{~cm})$. Because the number and locations of risers vary from tank to tank, access to waste is limited and representative sampling is very difficult. Because of the difficulty and cost of sampling, there was a very strong incentive to find a method for estimating the risk using the available information.

\subsubsection{Description of Wastes}

The majority of wastes stored in the underground tanks are radioactive slurries generated by irradiated uranium fuel reprocessing. The reprocessing generated acidic waste streams. Sodium hydroxide or calcium carbonate was added to the waste before it was transferred to the tanks. Post processing of some of the wastes to recover additional plutonium and uranium, or to reduce the volume of high-level waste, resulted in the addition of ferrocyanide and some organic compounds to the tanks. The tanks now contain a mixture of liquid, salt cake, and sludge.

The waste is mostly inorganic. It consists primarily of sodium hydroxide; sodium salts of nitrate, nitrite, carbonate, aluminate, phosphate; hydrous oxides of aluminum, iron, and manganese. The radioactive components consist primarily of mixed long-lived fission product radionuclides such as ${ }^{90} \mathrm{Sr},{ }^{137} \mathrm{Cs}$, and actinide elements such as uranium, plutonium, and americium.

Many of the tanks (SSTs) contain salt cake and very little free liquid. The moisture content of the salt cake can be quite high because of liquid trapped in the interstices of the salt cake. The salt cake is composed primarily of sodium hydroxide and nitrate/nitrite salts of sodium. The salt cakes were formed by evaporating liquid wastes to reduce volume. A slurry resulted that precipitated out the salt cake as it cooled.

The DSTs mainly hold liquids. Some of the DSTs have a floating crust with a composition similar to salt cake. The liquid is aqueous based and has a high concentration of sodium and hydroxide ions. These tanks are deliberately maintained at a high pH (11 to 14) to help prevent corrosion of the steel liners and the formation of unwanted compounds. Sodium hydroxide is sometimes added to the tanks to maintain the $\mathrm{pH}$ level. The liquid also contains organic complexant fragments resulting from the thermal and radiolytic decomposition of compounds such as glycolic acid, citric acid, and hydroxyethylethylenediaminetriacetic acid (HEDTA). These compounds were used as chelating agents for multivalent cations of plutonium and uranium.

The sludge, primarily found in the bottoms of SSTs, resulted from the dissolution of irradiated reactor fuel in nitric acid. They contain the dissolved fuel cladding. Sludge consists primarily of solids (hydrous metal oxides) precipitated from the neutralization of acid wastes.

The estimated 657,000 gal. $(2,487 \mathrm{~kJ})$ of TBP-NPH mixture that is the subject of this paper, can not be definitely tracked to particular tanks. Transfer records show that initial discharges went to multiple tanks. After initial discharge, much of it was included in tank-to-tank transfers. For safety analysis purposes, it is assumed that it could be in any of the tanks. 


\subsection{Development of Analysis Methodology}

The process of quantifying the risk involves identifying the potential accident scenarios, identifying the consequences of an accident (exposure to radioactive and toxic substances) and estimating the frequency of the accident. The magnitude of the consequences coupled with the frequency of the accident allows comparisons to be made with risk guidelines promulgated by the U.S. Department of Energy.

\subsection{Accident Scenarios}

The first step was to define the different configurations in which burning could occur. The configurations are.important because they have different ignition requirements. Also, the surface area burning and the speed at which the flame front propagates determine the pressure produced inside the tank. Three different configurations were identified.

1. Pool Fires - Pools are either a layer of solvent floating on top of liquid waste or solvent in a depression in a solid waste surface that is greater than $1 \mathrm{~m}^{2}$ in area. The size of a pool could be up to the entire surface area of a tank, $210 \mathrm{~m}^{2}$.

2. Puddle Fires - puddles are less than or equal to $1 \mathrm{~m}^{2}$ in area and exist in a depression in a solid waste surface.

3. Wick-Stabilized Fires - A wick-stabilized fire configuration would consist of a sludge or salt cake that is permeated with solvent. The height of the solvent layer would be equal to the height of the solids. The sludge or salt cake would act as a wick, and the solvent would burn. Wick-stabilized fires are also significantly easier to start than pool or puddle fires. The following analyses will show that the absolute consequences of this type of fire are less than those of a pool or puddle fire.

However, the probability of starting this fire will be significantly higher and is in a higher probability bin. Therefor the risk of this type of fire (risk is a function of both consequences and frequency) may be greater than the other types of fires.

Because neither the total number of tanks with separable phase organic layers nor the solvent configurations are known, it is not possible to use a single scenario to bound this accident. Instead, several scenarios, each of which maximizes a different result, were analyzed. The four results that were maximized were:

1. Tank pressure.

2. Tank vacuum.

3. Radiological release.

4. Toxicological release. 
Each of the four results was calculated for the different combinations of solvent fire configurations (pool, puddle and wick-stabilized), tank type (SST and DST) and type of ventilation system (active or passive). A matrix containing 18 different scenarios resulted. The maximum tank pressure and maximum tank vacuum results evaluate whether or not a tank would fail and open additional paths to the environment. The maximum pressure and vacuum cases did not result in dome collapse or a loss of liquid confinement as a result of structural damage to the tanks. Therefore the other two results, maximum radiological and maximum toxic consequences, calculated on the basis of waste being ejected from the ventilation systems and risers, produced the highest consequences. Ten scenarios were selected from the 18 to bound the potential accident consequences.

\subsection{Consequence Calculations}

Accident consequences result from the release of radioactive and toxic materials from the tank. The two contributors to the radiation and toxic doses are the material that has accumulated over time on the HEPA filters, which are assumed to rupture as a result of the pressure generated by a solvent fire, and the material released from the tank as a result of the fire. The materials released by the fire include solvent smoke, headspace gases, and aqueous boiloff.

The HEPA filters are assumed to have accumulated particles of tank waste. A safety requirement at the Hanford Site requires that HEPA filters be changed if the radiation dose measured at the filter housing is 0.2 Radiation Equivalents Man (REM). A back calculation using the 0.2 REM $\left(2 \times 10^{-3} \mathrm{~Sv}\right.$ [Sieverts]) and the radionuclide concentrations in the tanks results in an estimate of the quantity of tank waste that is on the filter. This quantity is then used for both radiation and toxic release calculations.

Solvent smoke is used to include the airborne release of the radionuclides content of burning solvent, the release of phosphorus pentoxide $\left(\mathrm{P}_{2} \mathrm{O}_{5}\right)$, carbon monoxide, and nitrous oxide combustion products from the burning solvent, and soot resulting from incomplete combustion of the solvent.

Headspace gases can contain a number of toxic substances. A bounding (worst case), steadystate composition was assumed on the basis of samples taken from the headspace of tank 241-C-103, the only tank known to have a solvent pool. It was assumed that the pressure generated by the solvent fire pushed the gases in the headspace out through the ventilation system.

\subsection{Frequencies}

The frequencies with which large energy sources come in contact with waste were estimated by reviewing tank farm equipment, operations, and natural phenomena. These energy source frequencies are combined with ignition probabilities (given the energy source is present) to assign ignition frequencies for solvent fires on a per-tank basis. The number of tanks that might contain combustible solvent configurations are estimated and used as a multiplier for per-tank frequencies. Accident scenario frequencies can be compared to risk evaluation guidelines. 
The evaluation concluded that all solvent pools and puddles require a very robust ignition source. Potential ignition sources for pool fires are few and limited to low frequency incidents of lightning strikes and vehicle fuel spill/ignition accidents. Wick-stabilized fires can be ignited with smaller energy sources. Potential ignition sources for wick-stabilized fires are more numerous and more likely. They include accidents with welding equipment, torch cutting, and use of some core sampling equipment. On a per-tank basis, where a combustible solvent configuration is contained in the tank, the frequency of ignition for pool fires is "extremely unlikely" ( $1 \times 10^{-4}$ to $1 \times 10^{-6}$ events per year) and the ignition frequency for wick-stabilized fires is "unlikely" ( $1 \times 10^{-2}$ to $1 \times 10^{-4}$ events per year). When per-tank ignition frequencies are combined with an estimate of the number of tanks that may contain a combustible solvent configuration, the frequency of the accident on a total facility basis is obtained.

\subsection{Assumptions Used in the Analyses}

It was necessary to make a series of assumptions in order to perform the consequence calculations needed to estimate risk. Because this is safety analysis and limited measured data was available, the assumptions tend to be Homeric, in order to predict consequences that would not be exceeded if the calculations were made with all the measured data an analyst desired. Another term for this type of calculation is "bounding" calculation.

\subsection{Properties of Solvent}

One tank has been sampled that contains a definite, separable layer of solvent. The composition of the solvent is approximately $30 \% \mathrm{NPH}$ and $70 \% \mathrm{TBP}$. This composition is consistent with the expected thermal and radiation induced degradation of the original mixture. Besides identifying the compounds, laboratory testing also established the flashpoint of the solvent and vapor concentrations at three temperatures. However, in order to perform the consequence calculations, more information was needed. Specifically the following parameters were needed.

\subsubsection{Ignition and Flame Spread}

The ignition of a stable flame over a circular area $0.3-\mathrm{m}$-diameter is postulated as the initial flame configuration. The flame is postulated to spread at a specified radial velocity until the entire pool area is covered by flame or until the fire is extinguished on low oxygen level. A bounding spread velocity is $10 \mathrm{~cm} / \mathrm{s}$. This value was selected after reviewing measured sire spread rates in large-scale open air tests with jet fuel (Leonard et al. 1992). Spread rates in the range of $8 \mathrm{~cm} / \mathrm{s}$ to $10 \mathrm{~cm} / \mathrm{s}$ were reported for initial fuel temperatures that were $10^{\circ} \mathrm{C}$ or more subcooled with respect to the flash point. While the data for jet fuel may not apply directly to confined solvent fires, the reported tests provide an experimental basis for defining an upper bound of approximately $10 \mathrm{~cm} / \mathrm{s}$ for spread velocity in waste tanks, because jet fuel is more flammable than the original fresh solvent that was sent to the tanks. 


\subsubsection{Solvent Pool Area}

Two cases of pool area were used to bracket possible pool sizes. First, a pool of $1 \mathrm{~m}^{2}$, termed a puddle, is postulated as a lower limit to be considered. Second, a large pool is postulated such that inflamed area is not limited by pool size. For the large diameter tanks, a pool area of $210 \mathrm{~m}^{2}$ is used to quantify the large pool case. For pools this size and larger, the fire was computed to extinguish on low oxygen level before the entire $210 \mathrm{~m}^{2}$ became inflamed. For the smaller diameter tanks a puddle fire case $\left(1 \mathrm{~m}^{2}\right)$ and a pool that covered the entire tank cross section. were analyzed.

\subsubsection{Fire Extinguishment}

The fire is assumed to extinguish at an oxygen concentration of 13 percent by volume. This assumption is based on the results of large-scale solvent pool fire tests in ventilated cells. The tests were conducted with NPH/TBP mixtures. The tests conducted by Jordan and Lindner (1983) reported a range of 11 to 17.5 percent. Tests by Malet et al (1983) reported results in a range of 13 to 14.5 percent.

I $t$ is also assumed that there is enough solvent present for combustion to continue until the oxygen extinguishment level is reached, rather than having the combustion stop due to lack of fuel.

\subsection{Tank Parameters}

All cases assumed the waste level of the tank with the smallest inventory. This assumption maximizes the volume of air in the dome space of he tank so that combustion is maximized.

\subsubsection{Vent Paths}

Vent paths were postulated at two extremes to cover possible cases. A minimal vent was postulated to evaluate maximum pressures that could be generated by a pool fire. For SSTs, this minimal vent path size was based on the HEPA vent pipe. For DSTs, the minimal vent was zero, a conservative default value chosen because of a lack of reliable information. A large vent path case was considered to evaluate maximum vacuum during cooldown after the fire has extinguished. A circular opening, $1.27 \mathrm{~m}$ in diameter, covered by a hinged plate was assumed to open at a pressure difference of 1 psi $(6.9 \mathrm{kPa})$. This flapper valve was hypothesized to simulate venting through large risers that are covered by caps held in place by gravity.

\subsubsection{Tank Structural Integrity}

All cases considered are analyzed on the assumption that thermal and mechanical loads imposed on tank structures by the postulated pool fire do not result in structural failure of the tank. A separate structural analysis, not described in the paper, established the pressures, vacuums and temperatures that could result in structural failure. The pressures and vacuums calculated in this 
report are within the boundaries established in the structural analysis. Therefore, radioactive material release attributable to tank structural failure is not considered.

\subsection{Models Used For Calculations}

\subsection{Thermal Hydraulic Modeling of Solvent Pool Fires.}

The Hanford Site waste tanks are gas-tight structures except for several relatively small vent pipes. A combustion of fuels in the confined air volume would heat the air and cause an increase in internal pressure. The peak pressure that can develop from a fire depends on how rapidly heat energy is evolved compared to the rate at which energy can be dissipated through heat transfer to tank surfaces and by gas outflow through leak paths.

Internal gas pressure and temperature were computed as a function of time by performing energy and mass balances on the air inventory in the tank for relatively short ( 0.1 to 1 second) time steps. Conditions at the end of a time step are used as initial conditions for the next step. Numerical evaluations are accomplished by means of a computer program called POOLFIRE.4, written for this specific application. It was written by G\&P Consultants, using the GW BASIC programming language. The program was used to predict the following key parameters, tank internal pressure, quantity of organic burned, quantity of gas vented from tank, and temperature of tank surfaces.

Using these parameters, the program calculated:

- Peak pressure in the tank

- Peak vacuum in the tank

- Mass of solvent burned

- Duration of the vent period from the tank

- Fractions of gases ejected from the tank.

\subsection{EXCEL Spreadsheet}

An Excel ${ }^{2}$ spreadsheet used the output from POOLFIRE 4 and calculated the radiological and toxicological consequences of the different accident scenarios. Eighteen solvent fire cases were evaluated in an effort to quantify bounding consequences for SSTs and DSTs. Calculations were carried out in three work sheets. The outputs of the spreadsheet were the radiological doses and toxicological doses for the 100 meter person and the offsite public.

\footnotetext{
${ }^{1}$ GW BASIC is trademark of Microsoft Inc., Redmond, Washington.

${ }^{2}$ Excel is a trademark of Microsoft Inc., Redmond, Washington.
} 
Figure 4-1. Final Safety Analysis Report Solvent Pool Fire Cases.

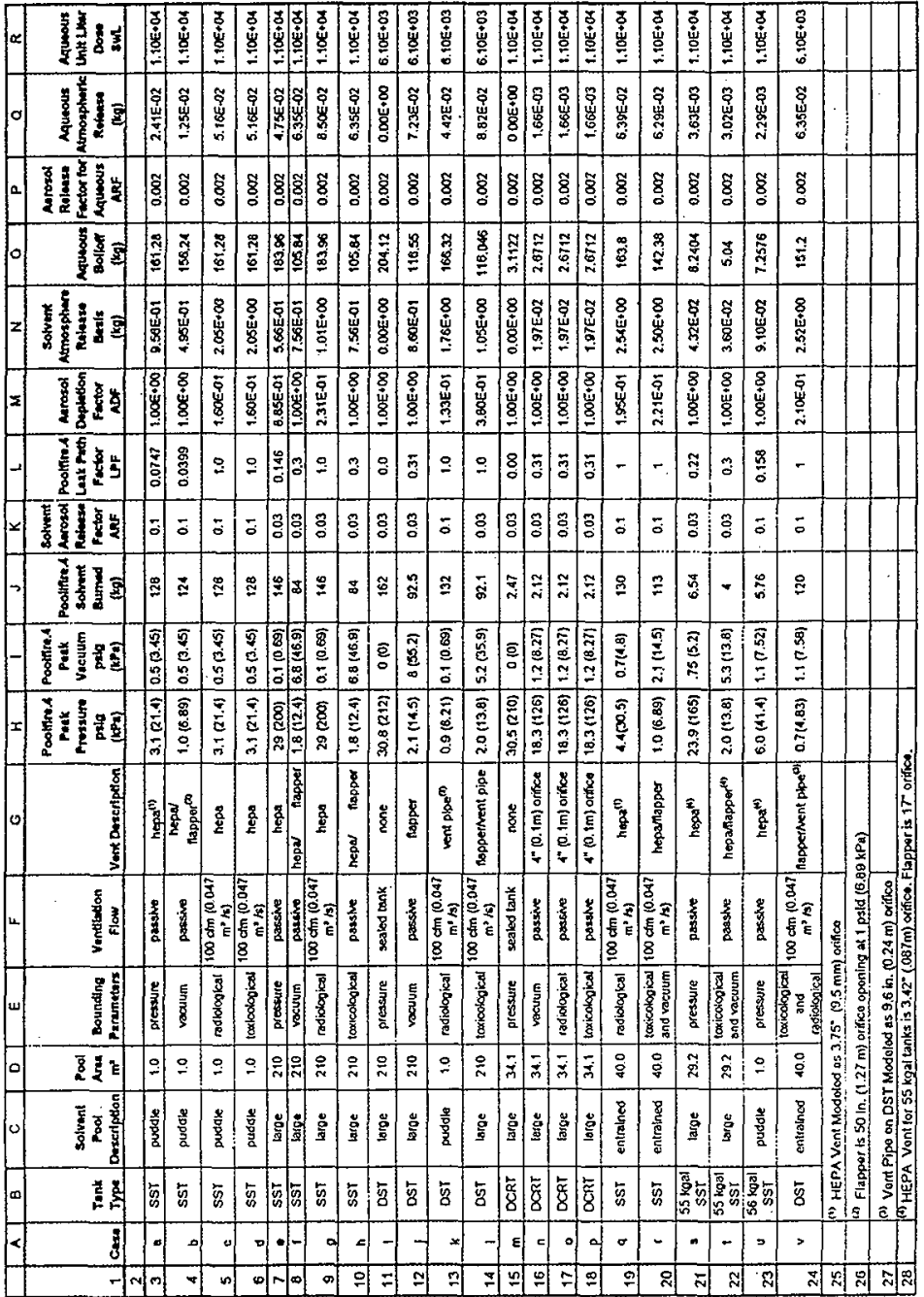




\subsubsection{Worksheet 1, Solvent Pool Fire Cases}

Figure 4-1 shows this worksheet (WS1). Each entry is described as follows.

\section{Column A}

Assigns case numbers on an alphabetic lettering sequence. Case letters carry over as the first column on each page of the workbook.

\section{Column B}

Identifies the type of waste tank considered for each case.

$\begin{array}{lll}\text { SST } & = & \text { single-shell tank } \\ \text { DST } & = & \text { double-shell tank } \\ \text { DCRT } & = & \text { double-contained receiver tank } \\ 55 \mathrm{kgal} \mathrm{SST} & = & 55,000 \text { gal }(208 \mathrm{~kL}) \text { single-shell tank }\end{array}$

\section{Column C}

Describes the size of pool analyzed for each case.

\section{Column D}

Lists the pool surface area assumed for each case.

\section{Column E}

Identifies the parameter (a consequence of a fire) that is maximized for the stated case. For example, Cell E3 identifies "pressure" as the parameter. The highest pressure for the puddle fire (case $A$ ) results from assuming the minimal vent path (the HEPA vent) for this case. The parameter "vacuum" indicates that vent path configuration was selected to cause the highest possible tank vacuum following fire extinction and the cooldown of headspace gases.

"Radiological" and "toxicological" descriptors indicate the cases were designed to yield bounding radiological and toxicological consequences, respectively.

\section{Column F}

Describes the type of ventilation assumed for each case. "Passive" applies to SSTs and DCRTs where ventilation is caused by atmospheric breathing and natural convection. The ventilation flow for actively ventilated tanks is listed as " $100 \mathrm{cfm}\left(0.047 \mathrm{~m}^{3} / \mathrm{s}\right)$ ". This flow rate designator was used to remind the analyst that ventilation flow rates in actively 
ventilated tanks are in the order of $100 \mathrm{cfm}\left(0.047 \mathrm{M}^{3} / \mathrm{s}\right)$ under normal conditions. This flow rate number is used when estimating aerosol depletion by in-tank sedimentation.

\section{Column G}

Lists the type of vent path assumed for each case. Footnotes 1 through 4 quantify the size of the equivalent orifice used in POOLFIRE. 4 calculations.

Cases I and $M$ are specified to have "none." Because available information is insufficient to characterize the minimal vent opening for DSTs and DCRTs, a default value of zero was assumed for these cases. Peak pressures computed for these cases is a conservative upper bound on pressures which could be generated by pool fires in these tanks. Separate structural studies determined that neither the DSTs nor DCRTs would fail at the maximum pressure generated.

\section{Column H}

Lists the peak pressure computed by POOLFIRE. 4 for each case. POOLFIRE. 4 calculates specific burning rate as a function of oxygen concentration in headspace air. All cases analyzed here use a bounding high value of $10 \mathrm{~cm} / \mathrm{s}$ for fire spread velocity.

\section{Column I}

Lists the peak vacuum inside the tank referenced to the outside atmosphere for each case. Headspace air pressure is computed as a function of time by POOLFIRE.4, and the numbers in column I are minimum gauge pressures from nuns with POOLFIRE. 4.

\section{Column $J$}

Lists the mass of solvent burned from fire initiation to fire extinguishment at an oxygen level of 13 mole percent for each case. These numbers come from runs with POOLFIRE.4. Note that cases with small vents result in the highest mass of solvent burned. The venting of oxygen from the tank leaves less oxygen in the tank to oxidize fuel; therefore, less fuel burns when larger vent paths are specified.

\section{Column K}

Lists aerosol release fraction (ARF) for each case analyzed. Puddle fires use $A R F=0.1$ and large pool fires use $A R F=0.03$. The ARFs were taken from Mishima (1994) 


\section{Column $\mathbf{L}$}

Lists the leak path factor (LPF), defined as the fraction of reaction products released from the tank during the course of a pool fire, for each case. For passively ventilated tanks, the numbers in this column are values calculated by POOLFIRE.4. For actively ventilated tanks, a default value of unity is assumed. This factor is calculated on the basis of zero depletion, i.e., on ideal gas behavior.

\section{Column M}

Lists the aerosol depletion factor $(\mathrm{ADF})$, defined as the ratio of aerosol mass leaked to the mass of aerosol which would leak if no depletion took place, for each case. The ADF is a transmission factor for aerosol mass. An ADF of 1.0 indicates that no depletion by aerosol deposition is predicted; a value of 0.16 indicates that in-tank sedimentation is calculated to reduce leaked aerosol mass to 16 percent of the mass leaked based on ideal gas behavior.

The LPF (see column L), the fractional leakage of contaminants based on ideal gas behavior times $\mathrm{ADF}$ is the fractional leakage of particulate contaminants predicted for solvent fires.

\section{Column N}

Calculates the solvent release from the tank to the environs (mass in $\mathrm{kg}$ ) and assigns $\mathrm{C} \mathrm{a}$

$$
\mathrm{S}=\mathrm{M} * 1 * \mathrm{ARF} * \mathrm{LPF}
$$

Where

$\mathrm{S}=$ source term, $\mathrm{kg}$

$\mathrm{M} \quad=$ mass of material at risk, $\mathrm{kg}$

$\mathrm{C}=$ concentration of contaminant in material at risk, $\mathrm{kg} / \mathrm{kg}$

$\mathrm{ARF}=$ aerosol release fraction (fraction of contaminant in material at risk which is released as an aerosol), dimensionless

LPF = leak path factor (fraction of aerosol which escapes to the enviornment), dimensionless.

default value of unity.

$$
\mathrm{N} 3=\mathrm{J} 3 * \mathrm{~K} 3 * \mathrm{~L} 3 * \mathrm{M} 3 .
$$

The Excel ${ }^{\mathrm{TM}}$ equation for Cell $\mathrm{N} 3$ is: 
This equation is reproduced in all rows by advancing the row number appropriately. The release of contaminants in the solvent may be quantified by muttiplying their concentrations by the solvent mass releases calculated in column $\mathrm{N}$. This mass release is also the appropriate mass to be used for computing doses using ULD values.

\section{Column O}

$$
\text { aqueous mass }=\text { fuel bumed } * 1.26
$$

Calculates the mass of water evaporated;

$$
\mathrm{O} 3=1.26 * \mathrm{~J} 3
$$

The Excel ${ }^{\mathrm{TM}}$ equation, for Cell O3, is:

\section{Column $\mathbf{P}$}

Assigns a value of 0.002 to the ARF for water evaporation for all cases. This ARF is cited as a bounding value for boiling liquids by Mishima (1994).

\section{Column Q}

$$
S=M * 1 * A R F * L P F .
$$

Using the same equation as Column $\mathrm{N}$, calculates the atmospheric release of aqueous waste caused by evaporation and assigns $\mathrm{C}$ a default value of unity:

$$
\mathrm{Q} 3=\mathrm{O} 3 * \mathrm{P} 3 * \mathrm{~L} 3 * \mathrm{M} 3
$$

The Excel ${ }^{\mathrm{TM}}$ equation for Cell Q3 is:

This equation is reproduced in all rows by advancing the row number appropriately. The ADF has been included to account for in-tank sedimentation of particulate contaminants. 


\section{Column R}

Lists the unit liter doses for liquid waste, the waste subject to evaporative release for each case. Unit Liter Doses (ULD) is a unit of measure for calculating radiological dose consequences. It is the inhalation dose in Sieverts per liter resulting from the release of one liter of tank waste.

\subsubsection{Worksheet 2, Dose Summary}

Worksheet 2 calculates on-site and off-site radiological doses for each of the cases shown on Worksheet 1. Because the main point of this paper is not calculating radiological consequences, Worksheet 2 is not included in this paper. The radiological doses calculated by Worksheet 2 are given in Section 5 of this paper.

\subsubsection{Worksheet 3, Toxicological}

A work sheet consisting of 11 pages performs the calculations for toxicological consequences. Because of the length of the spreadsheet, and the fact that this paper is not focused on consequence calculations, the spreadsheet is not included in this paper. The toxic consequences calculated by the spreadsheet are given in Section 5 .

At the Hanford Site, the consequences because of the release of toxic materials are calculated using Emergency Response Planning Guides (ERPGs) to measure the health effects of each constituent of a release. The frequency of a release is evaluated by assigning larger or smaller ERPGs to the constituents, depending on the frequency category determined for the accident. The health effects are summed using a technique called the Sum of Fraction (SOF), which results in a dimensionless number. If the SOF is less than 1 , risk evaluation guidelines have been met.

\subsection{Results}

The bounding cases that resulted from the analysis are shown in Table 5.1. Each of the cases maximizes one of the parameters for a type of tank. The maximum consequences are represented by a subset of these cases. The subset cases having bounding consequences are shown in Table 5.2. There are several reasons that more than one bounding case is used.

The probability of ignition for wick-stabilized fires and pool/puddle fires is significantly different. The wick-stabilized fires have a higher probability of occurrence (they are easier to ignite). The consequences of a wick-stabilized fire are less than the consequences of a $\mathrm{pool} / \mathrm{puddle}$ fire. However, risk is defined as a function of both consequences and probability. Both types of fires must be considered because we are looking at total risk.

DSTs and SSTs are analyzed separately because of differences in structural properties and ventilation systems. 
Finally, more SST cases are analyzed because the maximum radiological and toxicological doses do not occur in the same configuration. For DSTs, the same configuration produces both the maximum radiological and toxicological consequences.

Table 5.2 also shows the radiological and toxicological consequences calculated for the bounding cases, along with the applicable regulatory guidelines for comparison. As stated at the beginning of this report, all the consequences fall within the regulatory guidelines.

The far right column of Table 5.2 includes a frequency category. The unlikely frequency category is the range of $1 \times 10^{-2}$ to $1 \times 10^{-4}$ occurrences per year. The accident frequency category is relevant to selecting the correct regulatory guidelines.

The title of Table 5.2, as well as the final column heading mention "controls". Controls are engineered features or administrative actions specified to reduce either the consequences of an accident or prevent the accident. In the case of the solvent fire, the controls prevent or restrict . ignition sources to prevent the accident or reduce its frequency. The Nuclear Regulatory Commission and U. S. Department of Energy Orders also refer to these measures as Technical Safety Requirements.

\subsection{Conclusions}

The purpose of the analysis described in this paper was to determine if a potential accident in the Hanford Site underground storage tanks would exceed risk guidelines established by the DOE for protection of Hanford Site workers and the public. The accident is a fire burning degraded solvent found in some of the tanks at the Hanford Site.

There were two areas of uncertainty that the analysis had to deal with. The first was that samples of the solvent were available from only one tank, and the number of analyses that had been performed on the solvent for physical properties was limited. The second uncertainty was how many tanks contained a separable solvent phase. The authors chose to address the problems by performing a bounding analysis to determine if the consequences of the postulated accident fell within DOE guidelines. If the consequences were within guidelines, then further work was not required. If guidelines were not met, then more sophisticated analyses and/or more sampling would be required.

In Section 3, the bounding properties and assumptions used in the analysis are described. As stated in that section, many of the assumptions are Homeric (i.e., using a fire spread rate of diesel fuel on the deck of an aircraft carrier for burning a degraded solvent mixture in an enclosed area). The advantage of the assumptions is that the properties and assumptions can be justified as being bounding on the basis of the limited information available. It is nearly impossible to say that the analysis is understated or not conservative in terms of the assumptions used. 
In Section 5, the results of the calculations show that DOE risk evaluation guidelines are met, even using the Homeric assumptions. Because of the assumptions, it is possible to state that there is a significant, but not quantified, margin between the actual risk and the risk guidelines that is greater than shown by the calculations. This is a basis for determining that the risk is acceptable, and that no further resources need to be expended to analyze the accident. Therefore the bounding analysis was successful. 
Table 5.1. Bounding Cases from Parametric Studies.

\begin{tabular}{|c|c|c|c|c|c|}
\hline Case & Tank type & $\begin{array}{l}\text { Bounding } \\
\text { parameter }\end{array}$ & $\begin{array}{c}\text { Radiological onsite } \\
\text { dose, Sv (rem) }\end{array}$ & $\begin{array}{l}\text { Toxic onsite } \\
\text { exposure (sum of } \\
\text { fractions) }\end{array}$ & $\begin{array}{c}\text { Pressure or } \\
\text { vacuum psig (kPa) }\end{array}$ \\
\hline $\begin{array}{l}\text { Q Wick-stabilized } \\
\text { fire in salt cake or } \\
\text { sludge }\end{array}$ & SST & Radiological dose & $\begin{array}{c}1.3 \mathrm{E}-02 \\
(1.3)\end{array}$ & & \\
\hline $\begin{array}{l}R \text { Wick-stabilized fire in } \\
\text { a salt cake or sludge }\end{array}$ & SST & $\begin{array}{l}\text { Toxic exposure } \\
\text { and Max Vacuum }\end{array}$ & & 3.6 & $\begin{array}{c}-2.1 \\
(-14.5) \\
\text { vacuum }\end{array}$ \\
\hline E Pool fire & SST passive vent & $\begin{array}{l}\text { Pressure }(9.5 \mathrm{~cm} \\
\text { oritice) }\end{array}$ & & & $\begin{array}{c}29 \\
(200)\end{array}$ \\
\hline F Pool fire & SST passive vent & $\begin{array}{l}\text { Vacuum (137 cm } \\
\text { orifice) }\end{array}$ & & & $\begin{array}{l}-6.8(-46.9) \\
\text { vacuum }\end{array}$ \\
\hline G Pool fire & SST active vent & Radiological dose & $\begin{array}{c}1.6 \mathrm{E}-02 \\
(1.6)\end{array}$ & . & \\
\hline H Pool fire & SST passive vent & Toxic exposure & & $9.4 \mathrm{E}-01$ & \\
\hline $\begin{array}{l}V \text { Wick-stabilized fire in } \\
\text { crust }\end{array}$ & DST active vent & $\begin{array}{l}\text { Radiological dose } \\
\text { and toxic exposure }\end{array}$ & $\begin{array}{c}4.7 \mathrm{E}-03 \\
(0.47)\end{array}$ & 1.1 & \\
\hline I Pool & DST & $\begin{array}{l}\text { Pressure (sealed } \\
\text { tank) }\end{array}$ & . & & $\begin{array}{l}30.8 \\
(212) \\
\end{array}$ \\
\hline J Pool & DST passive vent & $\begin{array}{l}\text { Vacuum }(127 \mathrm{~cm} \\
\text { orifice) }\end{array}$ & & & $\frac{-8}{(-55.2) \text { vacuum }}$ \\
\hline L Pool & $\begin{array}{l}\text { DST (100 cfm } \\
\text { active vent) }\end{array}$ & $\begin{array}{l}\text { Radiological dose } \\
\text { and toxic exposure }\end{array}$ & $\begin{array}{c}6.3 E-03 \\
(0.63)\end{array}$ & $9.9 \mathrm{E}-01$ & \\
\hline
\end{tabular}

DST $=$ double-shell tank. SST $=$ single-shell tank.
SV a Sieverts

rem $=$ radiation equivalent man 


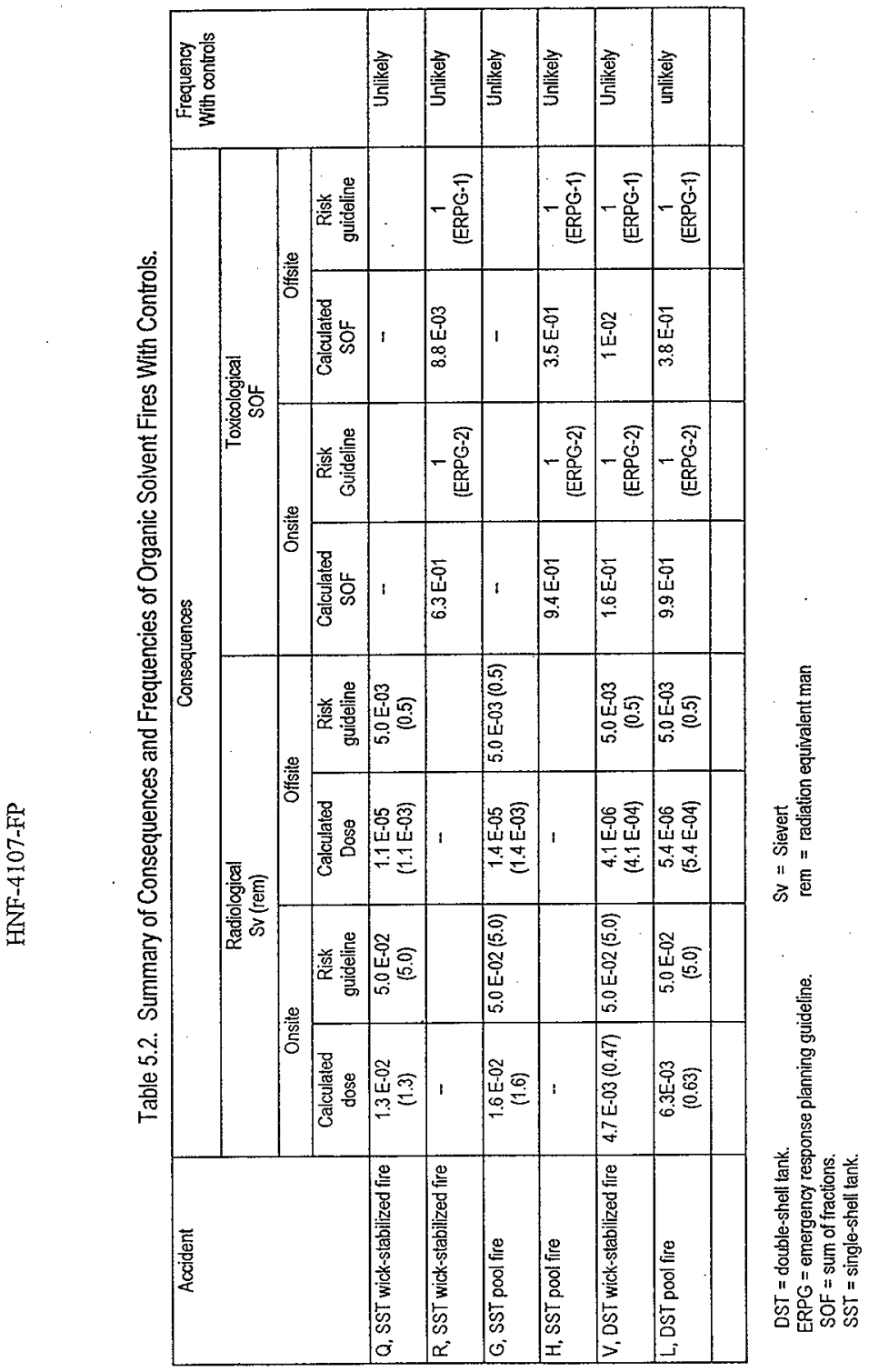




\subsection{References}

Jordan, S., and W. Lindner, 1983, "The Behavior of Burning Kerosene, Aerosol Formation and Consequences," in CSNI Specialist Meeting on Interaction of Fire and Explosion with Ventilation Systems in Nuclear Facilities Proceedings, April 25-28, 1983, Los Alamos, New Mexico.

Leonard, J. T., C. R. Fulper, R. Darwin, G. G. Back, R. E. Burns, and R. Ouelette, 1992, Fire Hazards of Mixed Fuels on the Flight Deck, Naval Research Laboratory, Washington, D.C.

Malet, J. C., G. Duverger de Cuy, R. Gasteiger, and K. Janberg, 1983, "Solvent Pool Fire Testing," in CNI Specialist Meeting on Interaction of Fire and Explosion with Ventilation Systems in Nuclear Facilities Proceedings, April 25-28, 1983, Los Alamos, New Mexico.

Mishima, J, 1994, Recommended Values and Technical Bases for Airborne Release Fractions, Airborne Release Rates and Respirable Fractions for Materials from Accidents in DOE Fuel Cycle, Ex-Reactor Facilities, DOE-HWBK-3010-94, Rev. 2, U.S. Department of Energy, Washington, D.C. 


\section{INFORMATION CLEARANCE FORM}

\section{A. Information Category}

\begin{tabular}{ll}
$\square$ Abstract & $\square$ Journal Article \\
$\square$ Summary & $\square$ Internet \\
$\square$ Visual Aid & $\square$ Sofware \\
$\square$ Full Paper & $\square$ Report \\
$\square$ Other & \\
\hline
\end{tabular}

B. Document Number HNF-4107-FP

C. Title

Evaluating Risk Using Bounding Calculations and Iimited Data

D. Internet Address william I bill cowleyerL.gov

\section{E. Required information}

1. Is document potentially classified? ONo OYes (MANDATORY)

\section{Manager's Signature Required}

If Yes ADC Signature Required

2. Internal Review Required?

if Yes, Document Signatures Below Ono OYes Classified

ONo Ores Counsel Program

3. References in the information are Applied Technology $O$ No $O$ Yes Export Controlled Information Ono Ores
4. Does Information Contain the Following: (MANDATORY)
a. New or Novel (Patentable) Subject Matter?
Ono Ores

If "Yes". Disclosure No.:

b. Information Recelved in Confidence, Such as Proprietary and/or Inventions? ONo OYes $\quad 1 f^{-Y e s *, ~ A f f i x ~ A p p r o p r i a t e ~ L e g e n d s / N o t i c e s . ~}$
c. Copyrights?
ONo
OYes
If "Yes", Attach Permission.
d. Trademarks?
Ono OYes
If "Yes", Identify in Document.

5. Is Information requiring submission to OSTi? $O$ No $O$ Yes

If Yes UCand $B \& R-$

6. Release Level? $($ Public $O$ Limited

7. Charge Code 101933

F. Complete for a Joumal Article

1. Title of Journal
G. Complete for a Presentation

1. Title for Conference or Meeting 1999 Spring Meeting

2. Group Sponsoring American Institute of Chemical Engineers
3. Date of Conference March 14 to 18
5. Will Information be Published in Proceedings? No OYes
W. Author/Requestor

4. City/State Houston, TX

6. Will Material be Handed Out? $\bigcirc$ No $\bigcirc$ Yes

1. Reviewers

Yes Print

Responsibje Manager

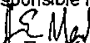

J. E. Heacham

(Print and Sign)
General Counsel
[
Kennte MnNoves
Office of External Affairs
DOE-RL
[a]
Debiat
MizLer
Other
if JON C.PESUHONG
Other

Signature

Public Y/N (II $N$, complete J)
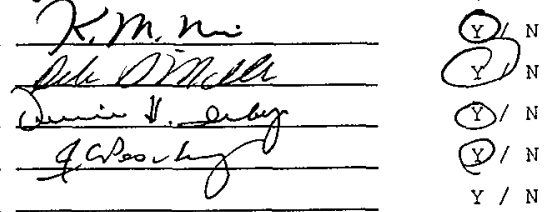

J. If Information Includes Sensitive Information and is not to be released to the Public indicate category below.
$\square$ Applied Technology
$\square$ Protected CRADA
$\square$ Personal/Private
$\square$ Export Controlled
$\square$ Proprietary
$\square$ Procurement-Sensitive
$\square$ Business-Sensitive
$\square$ Patentable
$\square$ Predecisiona!
$\square$ other (Specify)
$\square$ UCNI

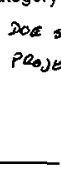
$\therefore$ Information Clearance Approva 


\section{RELEASE AUTHORIZATION}

Document Number: $\quad$ HNF-4107 -FP

Document Title:

Evaluating Risk Using Bounding Calculations and

Limited Data

This document, reviewed in accordance with DOE Order 241.1, "Scientific and Technical Information Management," and 241.1-1,

"Guide to the Management of Scientific and Technical Information," does not contain classified or sensitive unclassified information and is:

\section{APPROVED FOR PUBLIC RELEASE}

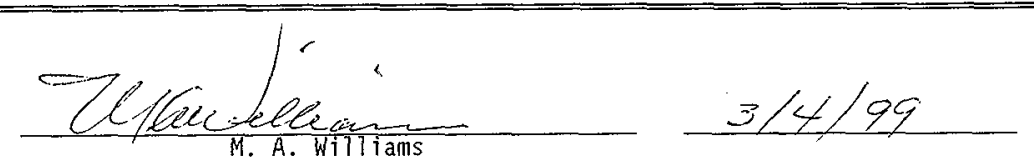

Lockheed Martin Services, Inc. Document Control/Information Clearance

Reviewed for Applied Technology, Business Sensitive, Classified, Copyrighted, Export Controlied, Patent, PersonalJPrivate, Proprietary.

Protected CRADA. Trademark, Unclassitied Controlled Nuclear Information.

COPYRIGHT LICENSE NOTICE. BY acceptance of this article, the publisher and/or recipient acknowledtes the U.S. Government's right to retain a nonexclusive. royalty-free license in and to any copyright covering this paper.

LEGAL DISCLAIMER. This report was prepared as an account of work sponsored by an agency of the United States Government. Neither the United States Government nor any agency thereof, not any of the ir employees. nor any of their contractors, subcontractors or their employees, makes any warranty. express or implied, or assumes any legal liability or responsibility for the accuracy, completeness, or any third party's use or the results of such use of any information, apparatus, product, or process disclosed, or represents that its use would not infringe privately owned rights. Reference herein to any specific commercial product, process, or service by trade name, trademark, manufacturer, or otherwise, does not necessarily constitute or imply its endorsement. recommendation, or favoring by the United States Government or any agency thereof or its contractors or subcontractors. The views and opinions of authors expressed herein do not necessarily state or refiect those of the United States Government or any agency thereof. This report has been reproduced from the best available copy. Printed in the United States of America. 